\title{
VIRGIN BIRTH AND BOWEL-MOVEMENT DEATH: EARLY COMMENTARY ON DANTE, INFERNO XI, 4-9
}

\begin{abstract}
Alexander McNair
The structure in allegory is thus somewhat complex. It declares the number three, among other things, and there is much beauty in it —or so the poet must have felt. Yet it is safe to guess that many a reader of the kind we so readily call "modern" will not share in the poet's feeling, even when such a structure is made visible to him in its broad outlines and several dimensions. With thought of such a reader, one might digress a moment to note our tendency to invoke his name whenever we wish to impute to the Middle Ages something which we sense is no longer to our taste, and note, too, that this "modern" is essentially a child of the Renaissance. It was in the time to which we give that much-debated name, a time (in Italy at least) following so closely on Dante's poem, that such relations as Dante has here affirmed in his three-fold structure were discredited as mere figments of the imagination. ${ }^{1}$
\end{abstract}

Thy Maker's maker, and thy father's mother,

Thou hast light in dark; and shutt'st in little room,

Immensity cloistered in thy dear womb. ${ }^{2}$

As Dante and Virgil leave the sixth circle of the Inferno, they are arrested by the stench wafting up from lower hell. More precisely, the stench is emitted — or "belched" as Hollander translates - by the deep abyss. The two poets can go no farther until their senses become accustomed to the smell, so they take cover beneath a tomb. Dante puts it this way:

e quivi, per l'orribile soperchio

del puzzo che 'l profondo abisso gitta,

ci raccostammo, in dietro, ad un coperchio

d'un grand' avello, ov' io vidi una scritta

che dicea: "Anastasio papa guardo,

lo qual trasse Fotin de la via dritta."

and here, because of the the horrible excess of stink which the deep abyss emits, we drew ourselves backward to the lid of a large tomb,

\footnotetext{
${ }^{1}$ Charles S. Singleton, Journey to Beatrice (Cambridge, MA: Harvard University Press, 1967), 95.

2 John Donne, "Holy Sonnets: Annunciation," in The Complete English Poems, ed. A.J. Smith (London: Penguin, 1996), 306.
} 
where I saw an inscription that said: "I watch over Pope Anastasius, whom Photinus drew from the straight way.",

This essay is about that inscription and its significance, but I would like to dwell on the smell for a moment longer, for reasons that will become apparent in due course. Dante uses the stench as an excuse to pause in the journey and outline for the reader the structure of lower hell: "Alcun compenso . . . trova che 'l tempo non passi perduto" [find something to compensate so the time passed is not lost] (XI.13-15). Scholarly readers focus most of the attention they pay to Canto XI on the conversation between Virgil (master) and Dante (student), as the rationale behind divine punishments and their inferno-graphical locations are described with Aristotelian precision. ${ }^{4}$ Readers are forgiven, too, for overlooking the setting at this moment, perhaps because we are still enthralled by the interview we have just witnessed between Dante and Farinata (Canto $\mathrm{X}$ ) - a moment that has captivated generations of commentators and critics. ${ }^{5}$ But could the fetid air and the tomb behind which our pilgrims take cover have some function other than setting the scene or providing a station-identification break? The "horrible excess of stink" does contrast dramatically with the high-minded dialogue and revelations of Cantos XXI. Commentators from the fourteenth through the sixteenth centuries felt obligated to explain this malodorousness: Aristotle and Augustine, for example, were adduced as expert witnesses on the metaphysical significance of the physical sense of smell. Citing the Aeneid, Pietro Alighieri reminds us that his father most likely had a literary model in mind when appealing to this sense, for the doves who lead Aeneas to the Golden Bough in Virgil's epic are forced to dodge the noxious air over

\footnotetext{
${ }^{3}$ The translation here is mine, an overly literal rendering. I cite the Italian from The Inferno by Dante Alighieri, ed. and trans. Robert and Jean Hollander (New York: Random House-Anchor Books, 2002), 204; this edition and translation are also available online through the Princeton Dante Project (PDP). Italian text from the Paradiso will be cited from the PDP. Unless otherwise noted, literal prose translations following the Commedia verses in brackets are mine.

${ }^{4}$ See, for example, Pier Massimo Forni's reading of the canto, "Lectura Dantis: Inferno XI," in Lectura Dantis 4 (1989): n.p. http://www.brown.edu/Departments/Italian_Studies/ LD/numbers/04.html

${ }^{5}$ See, for example, Erich Auerbach, Mimesis: The Representation of Reality in Western Literature, trans. Willard R. Trask (Princeton, NJ: Princeton University Press, 1953), 174202.
} 
Lake Avernus_-"grave olentis Averni" (VI, 201)—a "baleful stench" in Dryden's translation. ${ }^{6}$

The early commentaries can often seem mere catalogs of loci antiqui, quotations from the ancients conferring authority on the text commented. We are left to wonder if the commentator clearly saw the analogies suggested by the juxtaposition of text and quotation: Dante and Virgil taken aback by the smell, prefigured in the moment before Aeneas and his guide, the Cumaean Sibyl, reach the Golden Bough or, perhaps more appropriately, a little later as they perform the sacrificial rites that will open the netherworld to them. Dryden translates:

And here th' access a gloomy grove defends,

And there th' unnavigable lake extends,

O'er whose unhappy waters, void of light,

No bird presumes to steer his airy flight;

Such deadly stenches from the depths arise,

And steaming sulphur, that infects the skies.

And give the name Avernus to the lake. (VI, 240-47)

For Dante, there is no Golden Bough, only an endorsement from Heaven, though something of dove and bough is, perhaps, reflected in the angel whose wand opens the previously barred gates of Dis in Inferno IX (8990). ${ }^{7}$ If there is indeed a "noxious stench" emanating from the Stygian swamp serving as a moat for the "woeful city" (Inferno IX, 31-32; Hollander's translation), this winged denizen of heaven, unlike the birds of Greek legend, is merely inconvenienced by it: "Dal volto rimovea quell' aere grasso, / menando la sinistra innanzi spesso; / e sol di quell' angoscia parea lasso" [From his face he removed that heavy air, waving his left [hand] before the thick air; and only from this anguish did he seem wearied] (IX, 82-84). In Virgil, a dramatic sacrifice performed by

\footnotetext{
${ }^{6}$ In citing the commentary tradition I am using the Dartmouth Dante Project (DDP), an extremely useful database developed by Robert Hollander. Translations, unless otherwise noted, of the Italian and Latin commentaries are mine. John Dryden's classic translation of Virgil is available online in a number of places; I use the edition in the Perseus 2.0 collection of ancient Greco-Roman materials (maintained by Tufts University, ed. Gregory Crane) for both the Latin original and Dryden's English version.

${ }^{7}$ The wings and wand are, of course, also reminiscent of the winged feet and staff of the classical messenger god Hermes-Mercury; on this episode see, in addition to the notes in Hollander's edition of Inferno, Guy P. Raffa, The Complete Danteworlds: A Reader's Guide to the Divine Comedy (Chicago: University of Chicago Press, 2009), 41-42; on the angelic function of the "heavenly messenger" episode, see Susanna Barsella, In the Light of Angels: Angelology and Cosmology in Dante's Divina Commedia (Florence: Olschki, 2010), especially 148-62.
} 
Aeneas and the Sibyl (four "sable bullocks," a "barren heifer," a lamb, and seven bulls [VI, 248-63]) is one of the keys to unlocking the secrets of the netherworld, while in Dante, the "secrets" are unlocked by Virgil, schoolmaster, leading a discussion in ethics to liven up his lecture on infernal geography. The stench that links these analogous episodes-one ancient, one medieval - promises a dramatic, earth-shattering opening (as in Virgil's epic), which Dante's scholastic exercise in Canto XI appears not to deliver. The analogy is stretched to the breaking point, it would seem, rather quickly; perhaps the literary model provides just another juicy detail, another erudite allusion for the initiated. Is this the case also for our tomb inscription? Is Dante merely accumulating details with his allusion to Pope Anastasius?

This essay is an attempt to answer those questions, through an exploration of the early commentaries. As Steven Botterill notes, "The ongoing rediscovery of the fourteenth- and fifteenth-century tradition of commentary on the Comedy has been probably the most exciting area of innovation in Dante studies for at least the past thirty years." 8 This innovation has been facilitated greatly by the accessibility of Dante commentaries in the Dante Dartmouth Project, an easily searchable database which contains "all the principal commentaries and most of the minor ones." Deborah Parker cautioned two decades ago, when the Dante Dartmouth Project (and the internet itself) was still in its infancy, that employing the database "as it is designed allows the user to produce a personal text—essentially one's own book - a highly subjective version that suggests that commentary is one large text, rather than a collection of books."10 This study, at the risk of reflecting a personalized and subjective reading of the Comedy, has the modest goal of demonstrating how a recovery of early commentaries, which are a record of Dante's earliest community of readers, has the capacity to illuminate areas of text that have remained unattended since the renaissance. My approach to the Comedy follows the work of Auerbach, Singleton, Hollander, and Freccero in a figural reading; the four-fold allegory of the theologians common in Dante's day, in my opinion, holds the key to interpreting the Comedy as its early readers would have read it. It is still a deeply

\footnotetext{
${ }^{8}$ Steven Botterill, "Reading, Writing, and Speech in the Fourteenth- and FifteenthCentury Commentaries on Dante's Comedy," in Interpreting Dante: Essays on the Traditions of Dante Commentary, ed. Paola Nasti and Claudia Rossignoli (Notre Dame, Indiana: University of Notre Dame Press, 2013), 18.

${ }^{9}$ Botterill, 17.

${ }^{10}$ Commentary and Ideology: Dante in the Renaissance (Durham and London: Duke University Press, 1993), 24.
} 
satisfying way of reading the text. ${ }^{11}$ In charting the differences between Dante's late-medieval readers and his early-modern ones, I suggest that those early commentaries allow us to push the lid off of Anastasius's tomb, peek inside, and understand its "several meanings" as his early readers may have understood them, or as Dante himself may have intended them. In the "Epistle to Can Grande" (which some attribute to Dante himself) the author writes, "it must be understood that the meaning of this work [the Comedy] is not of one kind only; rather the work may be described as 'polysemous,' that is, having several meanings; for the first meaning is that which is conveyed by the letter, and the next is that which is conveyed by what the letter signifies; the former of which is called literal, while the latter is called allegorical, or mystical [or moral, or anagogical]." 12 Even if Dante himself did not write this letter, we are in the presence of an early commentator providing us with a latemedieval interpretive paradigm. The smell from lower hell, for example, resonates with other texts and appears to connect Dante to Aeneas on one level, but it signifies on multiple levels simultaneously.

If Dante is only using the stench from lower hell as a narrative device - an excuse to pause and provide a preview of coming attractions - then perhaps he uses the space on the tomb, behind which they have taken cover, as just another opportunity to satirize the corrupt humans in charge of the divinely established Church. One recent critic has even gone so far as to suggest that Dante includes a pope among the heretics to show that heresy crosses party lines; assuming of course that Anastasius would be a Guelph, he is there only to prove that Farinata's Ghibillines do not have a monopoly on the $\sin ^{13}$ Hell is bipartisan.

\footnotetext{
${ }^{11}$ I appreciate the New-formalist approach of Teodolinda Barolini- "Dante is subject to the exigencies of form, but is supremely gifted at camouflaging the fact that form can dictate poetic choices; he ideologizes form in such a way as to draw our attention from it to the ideology it serves" (The Undivine Comedy: Detheologizing Dante [Princeton, New Jersey: Princeton University Press, 1992], 17) —and the present study will certainly illustrate some of the ways in which our poet takes advantage of form to press his theology. However, I am more interested in how this work (form and content) was interpreted by its earliest audience, and how its reception changed over the first couple of centuries.

12 Trans. Paget Toynbee, in the PDP (Epistle XIII, 20). Latin text is "sciendum est quod istius operis non est simplex sensus, ymo dici potest polysemos, hoc est plurium sensuum; nam primus sensus est qui habetur per litteram, alius est qui habetur per significata per litteram. Et primus dicitur litteralis, secundus vero allegoricus, sive moralis, sive anagogicus."

${ }^{13}$ Anna Maria Chiavacci Leonardi: "Dopo il gruppo dei grandi ghibellini citati nel canto $X$, il ricordare qui un papa vuole probabilmente significare che l'eresia non è fatto proprio di una parte politica (in questo caso l'antipapale), ma può colpire anche lo stesso vertice della Chiesa. Dante quindi non mette a caso questo nome, come nessun altro nel poema.
} 
Many modern commentators from Longfellow and Toynbee to Singleton and Hollander, to mention only the English-speakers, treat the tomb and its allusion as a mere landmark, like Shelley's Ozymandias: "Look on my Works, ye Mighty, and despair!" 14 Their notes focus on Dante's (and the medieval tradition's) confusion of Pope Anastasius with the emperor of the same name and the "possible sources" of what Hollander calls Dante's "garbled history." 15 Typically, annotated editions and translations also include explanations of the different bishops (or deacons) named Photinus, their heretical tendencies (Monophysite, Acacian, Eutychian, Ebionite, Photinian) and possible relationships with the pope (or emperor). ${ }^{16}$ Some of these notes require a dictionary of heresies and heresiarchs to understand. ${ }^{17}$

Come sempre, egli vuol distinguere l'ufficio ecclesiastico, la gerarchia in quanto tale, dalla garanzia di salvezza" (qtd. from the DDP database, 1991-1997; search term: "Anastasio").

${ }^{14}$ Farinata's statuesque presence in Canto $\mathrm{X}$ actually makes a better comparison with Ozymandias. I cite the digital edition of Percy Bysshe Shelley's poem at the Poetry Foundation website: http://www.poetryfoundation.org/learning/guide/238972\#poem.

${ }^{15}$ In the PDP commentary on Inferno XI, 8-9; comments omitted from the print version of Hollander's edition and notes (cf. 212).

${ }^{16}$ See, for example, the most recent commentary on this passage listed in the DDP, Nicola Fosca's (2003-2006): “Anastasio II, papa dal 496 al 498 ed oggi considerato santo, ebbe fama di essere eretico: avendo egli accolto benevolmente Fotino, diacono di Tessalonica e seguace dell'eresia monofisita diffusa da Acacio, venne accusato di favorire tale eresia. Dante si rifà probabilmente ad un documento (il Decretum di Graziano) che era al tempo stimato autentico, mentre oggi è ritenuto falso; su questa base, è inutile 'correggere' il poeta, che si basa sulle conoscenze del proprio tempo, accusandolo di aver equivocato sul personaggio, magari scambiando il papa Anastasio (come ritennero alcuni commentatori) con l'imperatore Anastasio I (491-518). Tuttavia c'è un altro Fotino da tener presente, e cioè Fotino vescovo di Sirmio, il quale, come si legge nelle Etimologie di Isidoro di Siviglia (VIII.v.36), con i suoi seguaci (i fotiniani) aderì all'eresia ebionita."

${ }^{17}$ The cramped, double-columned 647 pages of John Henry Blunt's Dictionary of Sects, Heresies, Ecclesiastical Parties, and Schools of Thought (London, Oxford, and Cambridge, 1874), for example. I have really found only one commentary that attempts to answer the question of why Dante chose the specific heresy he indicates by naming Anastasius at this point; i.e., not just indicating which heresy (the litteram), but what it means (significata per litteram): Rodney J. Payton, in his A Modern Reader's Guide to Dante's Inferno (New York and San Francisco: Peter Lang, 1992), writes that "at the tomb of Anastasius the travelers are in an area where the heresy that is punished is not that of epicureanism, but Acacianism which claims that Christ was conceived and born as are other men. This heresy, as a consequence, denies the Virgin any significance and through that any special symbolic significance to womankind, specifically to Beatrice as a symbol of divine love. This fact might explain why Dante, from all the vast catalog of medieval heresies, chose to allude to Acacianism at this point" (79). Acacianism, as we will see and as the humanists pointed out, is not actually the denial of the Virgin birth as Dante believed, but Payton's remarks are extremely perceptive. 
Nit-picking Dante's "confusion" in this way actually began in the late fifteenth- and sixteenth-century commentaries. The spirit of humanism and its interest in historical accuracy informs early modern and modern annotators alike, who attempt to reconstruct Dante's ignorance as medieval context for the reader. ${ }^{18}$ Giovan Battista Gelli is one such humanist and his commentary (1541-1563) exemplifies this practice. After confirming that the poet refers to Anastasius IIAlessandro Vellutello, in 1544, had asserted the reference was to Anastasius IV - and providing a brief biography of the pope, as most commentators do, Gelli expresses his doubt that Dante and previous commentators have correctly identified Photinus:

. . because he cannot be, as the expositors commonly understand, the Gallo-grecian Photinus, Bishop of Smirna, from whom the Photinian heretics take their name, for he was the inventor and instigator of the Ebionitic heresy, which held that Christ was born of Mary and Joseph via the normal route of nature, and for which he was exiled by Emperor Valentinian, because this was around the year of our Lord 367; and Anastasius, as we have said, was made pope just before the year $500[\ldots]$ a difference between the one and the other of around 133 years. And if anyone claims that the Photinian heresy should be meant here because of this Photinus, saying that such heresy (he following it) drew him off the straight path, this is not true; because Anastasius did not fall into the Photinian heresy, according to what is read, but rather he fell into that [heresy] of Acacius, Patriarch of Constantinople, and of Abbot Eutychius, who denied Christ's human nature, and left Him only the divine. Because of which it is necessary either that this was a different Photinus than the one we have mentioned (and this could very well be, since Gratian names among the heretics in his Decretals another Photinus, who he says was a Thessalonican deacon), or that the text is corrupt and ought to say Plotinus instead of Photinus, which is what I rather believe... ${ }^{19}$

\footnotetext{
18 "Whereas early commentators considered it valuable to accumulate multiple interpretations of their predecessors to create compendia of the extant 'secondary literature' on Dante, modern literary scholarship on the Comedy is often keen to depart from the tradition and mark its originality, its new conquests, labeling commentaries of the past faulty and ignorant" (Paola Nasti and Claudia Rossignioli, "Introduction," in Interpreting Dante: Essays on the Traditions of Dante Commentary [Notre Dame, Indiana: University of Notre Dame Press, 2013], 8.).

${ }^{19}$ I translate from the DDP, Gelli's commentary on Inferno 11.6-9: "Perciò ch'ei non potesse essere, come intendono comunemente gli espositori, quel Fotino Gallogreco,
} 
Gelli's commentary offers an ingenious humanist explanation for Dante's "error" as the result of a copyist's misreading, a manuscript corruption in desperate need of correction; humanist to the rescue! This explanation, however, does not pretend to understand why Dante might have placed Anastasius and Photinus (whoever he might be) on this tomb inscription in the first place. The humanist commentary tradition, beginning with Cristoforo Landino in $1480,{ }^{20}$ was more concerned with setting the record straight about which heresy Dante should have been alluding to in mentioning Pope Anastasius and Photinus: one type of monophysitism, which in part led to the Acacian schism, and according to which Christ is of one nature, the divine.

Surveying the fourteenth- and early fifteenth-century commentaries, however, we find a different interpretation suggests itself. Dante and his early audiences may have had their history of heresy and heresiarchs wrong, but they are not at all confused about which heresy would be conjured in the reader's imagination at the mention of Anastasius and Photinus. For them, the most abominable of heresies was that in which Christ had a single nature, the human, which would in turn deny the

vescovo Smirnense, da 'l quale presero il nome gli eretici Fotiniani, per essere stato suscitatore e innovatore della eresia Ebionitica, la quale teneva che Cristo fusse nato di Maria e di Giosef secondo la via e il modo ordinario della natura; onde fu cacciato in esilio da Valentiniano Imperadore. Perciò che questo fu circa a gli anni del Signore 367; e Anastasio, che noi abbiamo detto, fu creato papa dipoi l'anno 500 [...] onde fu da l'uno a l'altro anni circa a 133. E se qualcuno dicesse ch'ei si ha intendere per questo Fotino la eresia Fotiniana, dicendo che quella, seguitandola egli, lo traesse fuor della via dritta, questo non è vero; perciò che Anastasio non cadde, secondo che si legge, nella eresia Fotiniana, ma cadde in quella di Acazio, Patriarca di Costantinopoli, e di Eutichio abate, i quali negavano in Cristo la natura umana, e lasciavangli solamente la divina. Per la qual cosa, o ei bisogna che questo fusse un altro Fotino, diverso da quello che noi abbiamo detto; e questo potrebbe molto bene essere, nominando Graziano nel Decreto fra gli eretici un altro Fotino, il quale ei dice che fu diacono Tessalonicense; o ei bisogna che il testo stia male, e abbia a dire, in cambio di Fotino, Plotino; il che io più tosto credo [...]."

${ }^{20}$ As Hollander notes, "the pause in commentary production between John of Serravalle (1416) and Cristoforo Landino (1480) serves to mark the passage from medieval to renaissance attitudes toward the poem" ("Dante and his Commentators," The Cambridge Companion to Dante, ed. Rachel Jacoff [Cambridge: Cambridge University Press, 1993], 229). In addition to Hollander's survey of the entire commentary tradition, see Steven Botterill's recent interpretation of the earliest commentators: "As a first attempt at sketching a historical taxonomy of the fourteenth- and fifteenth-century Comedy commentaries, I would argue that the tradition is characterized by three broadly defined phases, which together take the story of its development from the immediate aftermath of Dante's death (and the beginning of the completed Comedy's circulation history) in 1321 to the radical shift in methodology and interpretive assumptions heralded by the appearance of Cristoforo Landino's commentary — not insignificantly, the first to be printed —in 1481" ("Reading, Writing, and Speech,"19). 
Virgin birth. This is how almost all of the commentators before Landino understood the inscription's allusion and can also give us some indication about how Dante himself intended the inscription to function in his work. For now we will let Giovanni Boccaccio's commentary on the passage (1373-1375) speak for the rest:

[Anastasius] was, therefore, by this Photinus corrupted and brought from the Catholic faith and he fell into an abominable heresy, of which one named Acacius, a singular friend of Photinus, had been the inventor and seed-sower. And the heresy was this: that this Acacius affirmed Christ had not been the son of God, but of Joseph, and that he had begat him lying carnally with the Virgin; and thus it was not true that the Virgin Mary was virgin before the birth and after the birth, as Catholic Christians firmly believe. ${ }^{21}$

Most early commentators have it that Acacius was excommunicated, but that Photinus managed to convince Anastasius to restore Acacius to full communion with the Church, over the objections of the Roman clergy. Less than a decade after Dante's death, Guido da Pisa explains it this way:

Photinus, coming to Rome, drew Pope Anastasius II, of Roman birth, from the Catholic way and made him a heretic; whereby the clergy of the Roman Church rose up against him, and mostly because, at the insistence of this same Photinus, he wished to restore a certain heretic named Acacius after he had been condemned by the Roman Church. ${ }^{22}$

21 “...fu adunque da questo Fotino corrotto e tratto della catolica fede e cadde in una abominevole eresia, della quale era stato inventore e seminatore uno chiamato Acazio, singulare amico di Fotino. Ed era l' eresia questa: che questo Acazio affermava Cristo non essere stato figliuol di Dio, ma di Giuseppo, e ch'esso carnalmente giaccendo con la Vergine l' aveva acquistato; e così non era vero che la Virgine Maria fosse vergine inanzi il parto e dopo il parto, come i catolici cristiani fermamente credono..." (DDP).

${ }^{22}$ Guido da Pisa (1327-28): "Fotinus veniens Romam Anastasium Papam secundum, natione romanum, de via catholica extraxit et hereticum fecit. Unde clerici Romane Ecclesie contra ipsum insurrexerunt, et maxime quia petitionem ipsius Fotini quendam hereticum nomine Achasium restituere voluit, postquam damnatus fuerat per Ecclesiam Romanam" (DDP). Boccaccio conflates Photinus and Acacius at this point, stating that it was Photinus whom Anastasius attempted to restore to full communion: "per la quale eresia il detto Fotino fu dannato e rimosso dalla comunione de' cristiani. E volendolo questo Anastasio papa riducere nella comunione cristiana, essendosi contro a ciò levati molti santi padri, e a questo resistendo" (DDP). For these commentators, Photinus manages to convert Anastasius to Acacius's heresy, which they interpret as Christ with a single, human, nature: e.g., "si lo condusse a credere che in Cristo non fusse se non simpliciter una natura cioè umana" (Jacopo della Lana [1324-28] in the DDP). The Renaissance humanists are more 
According to these early commentaries divine judgment intervenes (divino iudicio or giudicio in Guido da Pisa, L'Ottimo Commento, Boccaccio) to prevent Anastasius from restoring Acacius. Again, Boccaccio's version is representative:

... and it happened that, the aforementioned [Anastasius] having been pope for one year, eleven months and twenty-three days, having gone to the secret place [segreto luogo, i.e., the latrine] where the superfluities of the gut are deposited, by divine judgment, as is universally believed by all, through his underparts [parti inferiori] he emitted and sent out of his body all of his insides and, thus, on that very spot he expired, miserably. ${ }^{23}$

As distasteful as this seems, Jacopo della Lana (1324-28) and Benvenuto da Imola (1375-80) are nearly alone among the early commentators in choosing not to relate the story of Anastasius II's bowel-movement death (the same fate that allegedly struck down the Alexandrian heretic Arius in the fourth century). Pietro Alighieri and Guido da Pisa tell it in Latin - "egerendo intestina miserabiliter expiravit" and "ibi egerendo omni intestina decessit" — both using the verb egero, egerere (to discharge, empty out). Some fourteenth-century Italian commentators use the verb gittare [to cast or emit] to describe how the hapless heretic crapped out his innards: "gittando fuori le intestine" (L'Ottimo Commento [1333]), "gittando fuori le budelle" (L'Ottimo Commento [1338]), "gittò e mandò fuori del corpo tutte le interiora" (Boccaccio), "per miracolo divino gittò fuori tutte le intestine" (Francesco da Buti $[1385]){ }^{24}$ The relish with which the early commentators repeated the

correct in pointing out that Acacius's heresy would have been monophysite, but of a very different type: Christ's nature is solely divine. It should be clarified that modern historians do not believe Anastasius II's theology to be anything but orthodox and Acacius, who at the time of his excommunication was Patriarch of Constantinople, is known less as a heresiarch than as a schismatic. Acacius tried to reconcile the monophysites and catholics at the insistence of Emperor Zeno, but his efforts were not ratified by the Roman pontiff, which led to a series of mutual excommunications and the Acacian schism which lasted nearly forty years (480-519 CE). For a brief account of the Acacian schism, see Adrian Fortescue's "Henoticon" article in The Catholic Encyclopedia, Vol. 7 (New York: Robert Appleton, 1910).

23 "avvenne che, essendo il detto papa seduto già un anno e undici mesi e ventitré dì, andato al segreto luogo dove le superfluità del ventre si dipongono, per divino giudicio, sì come per tutti universalmente si credette, per le parti inferiori gittò e mandò fuori del corpo tutte le interiora, e così miseramente nel luogo medesimo spirò."

${ }^{24}$ The sixteenth-century commentator Gelli, mentioned above, also uses this verb, appearing to follow Boccaccio on this point: "gittò fuori tutte l'interiora." Other possible constructions are much less active: Chiose Vernon's "gl'uscirono di corpo tutte le 'nteriore 
story of Anastasius' ignominious end is matched only by their horror at the heresy they believed he had fallen into, essentially a denial of the Incarnation. That verb, gittare, which the early commentators use to describe the action of the heretic sending his intestines out through his anus is, not so coincidently, the same verb Dante uses to describe the way in which the abyss exudes its stench: "l'orribile soperchio / del puzzo che 'l profondo abisso gitta" (XI, 4-5). If Dante intended his readers to connect hell's smell (physical and metaphysical) to the sin of Anastasius/Photinus, then the fourteenth-century commentaries appear to have made this connection on at least a lexical level. The gitta ties the heretics mentioned in the scritta not merely to hell's stench, as a bit of latrine humor, it also connects them to the larger structure of hell, which is itself a sort of digestive tract, terminating in Lucifer's parti inferiori: the center of gravity for Dante's physical universe, the point to which all the world's sewage must eventually come to rest. ${ }^{25}$

Filling out our triple rhyme scheme is the via dritta off of which Anastasius has been lead; the early commentaries linked this to the Church or the Faith: "La via dritta è la fede Catolica, fuori della quale neuno sarà salvo" (The straight way is the Catholic faith, outside of which none will be saved; L'Ottimo Commento [1333]). It recalls for the reader the diritta via that Dante had lost in the dark wood at the poem's opening. ${ }^{26}$ So the tomb inscription, the scritta, is linked to Dante's personal journey, leading him to the edge of the abyss which throws out, gitta, its horrible excess as Anastasius did his own intestines. Dante's terza rima connects these stories for us: the soperchio ("excess") of horrible stench is related to the coperchio (tomb's lid) on which we read the scritta. In the commentary tradition, the heretic's emitting (gitta) of

e anche l'anima" (all of his innards and even his soul left his body [1390]) or the Anonimo Fiorentino's "le interiora gli uscirono di soto" ("His insides ... came out from below" as Charles S. Singleton translates in his note on the passage [also in DDP], though the anonymous Florentine commentary of 1400 adds "sedendo et sforzandosi," which Singleton translates as "while he sat forcing himself"). Cristoforo Landino (1480) has the same formulation, varying only the word order: "gl' uscirono tutte le 'nteriora" (DDP).

${ }^{25}$ See Robert M. Durling, "The Body Analogy" in Divine Comedy: Inferno, ed. and trans. Robert Durling and Ronald L. Martinez (New York and Oxford: Oxford University Press, 1996), 552-55, 576-77. Also, Robert M. Durling, "Deceit and Digestion in the Belly of Hell" in Allegory and Representation, ed. Stephen J. Greenblatt (Baltimore and London: Johns Hopkins University Press, 1981), 61-93.

${ }^{26}$ Ronald L. Martinez also notes this connection between the inscription and Dante's lost way in "Anastasio papa guardo: The Descent into Hell and Dante's Heretics," Mediaevalia 29.2 (2008): 15-30, esp. 22. My thanks to the anonymous peer-reviewer who pointed me in the direction of this article, to which I will return in the conclusion. 
his intestines establishes a figural link between the physical world and the metaphysical horror emitted by the abyss in Dante's verse. But unlike Anastasius and Photinus, Dante has hope: the scritta can lead back to the via dritta, if one is prepared to read/interpret appropriately. Help has already come to him in the form of his poetic master Virgil, though Virgil could not talk his way into the gates of Dis without the help of another: the angelic visitor of Canto IX. Right before the angel's appearance Dante addresses the reader: "O voi ch' avette li 'ntelletti sani / mirate la dottrina che s'asconde / sotto 'l velame de li versi strani" [O you who have sound intellect look at the doctrine that is hidden beneath the veil of the strange verses] (61-63). The word "doctrine" seems to imply the teachings of the Church, so it might be useful to return to that heresy with which Dante and his contemporaries associated Anastasius and Photinus. The Virgin birth is central to the Nicene Creed (the most basic explanation of Christian doctrine), and not a mere adjunct to the Trinity. It is through the miracle of the Virgin birth that Christians understand that Christ is fully human and fully divine simultaneously; and salvation is only possible when God in the flesh experiences both the womb and the tomb. In commenting upon the final revelation of the mysteries of the Trinity and the Incarnation at the end of Paradiso, Christopher Ryan notes that "it is entirely apt that the final vision should end this way, for it may be said that the central quest of Dante's understanding in the poem, and indeed in his oeuvre as a whole, was to grasp how the divine is present in the human." 27 To the best of Dante's knowledge, the Incarnation is precisely what the heretics of our inscription denied.

In refuting this heresy L'Ottimo Commento (1333) reminds his readers of the Annunciation in Luke 1-"Missus est Angelus Gabriel a Deo" (The Angel Gabriel was sent by God; qtd. in DDP) - and perhaps Dante intends his reader to remember that missus est when he recognizes the angel as "dal ciel messo" (from heaven sent) in the "strange verses" of Canto IX. In fact, Dante's heavenly messenger scene encapsulates the full story of Incarnation: if the angelic vision recalls the Annunciation, the angel's actions also reenact the Harrowing. And this brings us back

\footnotetext{
27"“The Theology of Dante," in The Cambridge Companion to Dante, ed. Rachel Jacoff (Cambridge: Cambridge University Press, 1993), 136. On the Incarnation as central to the human ability to experience an "awakening of divine, self-subsistent Intellect to itself . . . to experience oneself as Christ, as both God and nature, thus bridging the infinite and the finite," see Christian Moevs, "Il punto che mi vinse: Incarnation, Revelation, and SelfKnowledge in Dante's Commedia" in Dante's Commedia: Theology as Poetry, ed. Vittorio Montemaggi and Matthew Traherne (Notre Dame, Indiana: University of Notre Dame Press, 2010), 267-85.
} 
around to our two epigraphs. The three-fold structure mentioned by Singleton and which is not to the taste of "modern" readers is not the terza rima stanza or even the tripartite afterlife (Hell, Purgatory, Heaven) - that would simply be "quaint." What readers since the Renaissance, and to an even greater extent since the Enlightenment, find difficult to accept is that the mythical coexists with (if not sustains) the historical in Dante. ${ }^{28}$ Singleton reminds us that in the events of Dante's story "we see, as in a mirror, the reflected outline of other events strangely resembling this ... disclosed in no less than three dimensions of time, in triple aspect: as it was, as it is, and as it shall be" (86). The figural interpretation that Dante almost certainly expected his readers to experience is not a simple decoding process: "this" means "that," as in, Virgil is really an allegory for the role that Reason plays in the soul's journey (Hollander has made this point emphatically in his work on allegory in Dante; sometimes Virgil is just Virgil). ${ }^{29}$ No, Dante's literal level does not have to stand for something else; it is a rip-roaring tale in its own right. But for those of sound intellect, these strange verses can simultaneously open up new dimensions for the reader: that timeless realm of myth, where the Incarnation occurred in a single historical moment, yet is present, and somehow also eternal ("Thy Maker's maker . . . immensity cloistered in thy dear womb"). ${ }^{30}$ Dante is not Paul or

${ }^{28}$ Cf. Auerbach: "Obviously Dante's conception of what happens, of history, is not identical with that commonly accepted in our modern world. Indeed, he does not view it merely as an earthly process, a pattern of earthly events, but in constant connection with God's plan, toward the goal of which all earthly happenings tend. [...] The goal of the process of salvation, the white rose in the Empyrean, the community of the elect in God's no longer veiled presence, is not only a certain hope for the future but is from all eternity perfect in God and prefigured for men, as is Christ in Adam" (Mimesis, 194).

${ }^{29}$ Allegory in Dante's Commedia (Princeton: Princeton University Press, 1969). See also his essay on "Allegory" in his introduction to Inferno (pp. xxix-xxxiii) and his lecture "Allegory in Dante" on the PDP. Hollander follows in the footsteps of Singleton, and ultimately Auerbach, in recognizing the allegory of the theologians as Dante's principal vehicle rather than the simple allegory of the poets (on this school of criticism see Hollander, "Dante and his Commentators," 234).

${ }^{30}$ Donne's lines on the Annunciation are wonderful in their poetic economy and are a convenient reference point as a result, but it should be noted that such formulations about the mystery of the Incarnation are not anachronistic. Dante's contemporaries and predecessors expressed themselves in similar terms. Guerric of Igny, for example, in the twelfth century reflects on the Annunciation: "I do not know if there is any more effective and pleasing form of moral training than the faithful and devout consideration of this mystery, that is, of the Word made flesh. For what could so arouse someone to the true love of God more than the fact that God's love anticipates human love and is so ardent for humanity that it desires to become man for man's sake? . . Behold the ineffable condescension of God together with the power of the unfathomable mystery! The one who created you is created in you, and as if it were too little that you should have him as a 
Aeneas, as he protests to Virgil at the beginning of the Comedy, much less Hercules or Theseus or Christ; he is just Dante on one level. But in that timeless, mythic dimension that Dante opens up for his reader, he can be consubstantial with them. Again, in the way of theological allegory, the character Dante constructs for himself (Dante-pilgrim as opposed to Dante-poet) can mean several things at once without ceasing to be Dante. ${ }^{31}$

Dante makes his way into lower hell as Theseus into the labyrinth and Christ into the tomb after Canto XI. And Canto XII reminds us of both events: finally accustomed to the stench, our travelers can make their way into the circle of violence, where they see (1) the rockslide, evidence of the earthquake that shook Hell at Christ's crucifixion, and (2) the Minotaur whom Theseus slew. If Anastasius could not accept that Christ was "light in dark . . immensity cloistered" in a womb - Durling and Martinez, by the way, point out that their names are etymologically "ironic puns," Anastasius is "the resurrected" and Photinus is the "little light" 32 - then he cannot be saved from his tomb. Dante probably thought it fitting that he should spend the rest of eternity in close proximity to the seed of a womb that can be read here as a monstrous perversion of the Incarnation: Pasiphae mating with the bull to produce the Minotaur"l'infamia di Creti . . . che fu concetta ne la falsa vacca" (XII, 12-13). Virgil taunts the Minotaur by reminding him of Theseus and the fact that he was instructed by the beast's own sister- "ammaestrato da la sua sorella" (XII, 20)—on how to kill him and escape from the labyrinth. We

Father, he also wants you to be his mother" ("Birthing in Patristic and Medieval Texts," in The Essential Writings of Christian Mysticism, ed. Bernard McGinn [New York: Modern Library, 2006], 405-06). For a compelling near-contemporary of Dante, see also Mechthild of Magdeburg's retelling of the Incarnation (a conversation within the Trinity itself) in The Flowing Light of the Godhead (excerpted in Essential Writings of Christian Mysticism, 205-07). On the centrality of Incarnation to the Commedia as a whole, see John Freccero: "The Incarnation is not only the final theme of the Paradiso, but also the moment that, from the standpoint of narrative logic, makes the poem possible" "Introduction to Inferno," in The Cambridge Companion to Dante, ed. Rachel Jacoff [Cambridge: Cambridge University Press, 1993], 189).

${ }^{31}$ John Freccero notes, following Singleton and Hollander, "only in a text of which God is the author can things both mean and be. From such a perspective, Joshua, for example, would not only be the man who led the Jews across the Jordan, he would also mean Jesus, whose name is the same as Joshua in Aramaic. Joshua existed, which is what is meant by the truth of the literal level, but he also functions as a figure for Christ. For this reason, he may be said to be a 'shadow-bearing preface' of his own truth (Paradiso 30, 75)" ("Introduction to Inferno" in Jacoff, 181).

${ }^{32}$ Robert M. Durling and Richard L. Martinez, ed. and trans., Divine Comedy: Inferno (New York and Oxford: Oxford University Press, 1996), 178n. 
are reminded that, likewise, it is a woman, Beatrice, moved by love ("amor mi mosse," Inferno II, 72), who initiates Dante's escape from the dark wood. And that Ariadne and Beatrice are, perhaps, imperfect reflections of the woman who brought salvation to mankind, the "Maker's maker" as Donne put it; Dante writes that the "Vergine Madre" has ennobled human nature because her "Maker" or Creator did not disdain becoming her creature: "che l'umana natura nobilitasti sí, che '1 suo fattore non disdegnò di farsi sua fattura" (Paradiso XXXIII, 4-6).

The inscription, the scritta that links the horrid verb gitta to the via dritta in Dante's triple-rhyme scheme, has its own secrets to unveil for the attentive reader; it points the reader back to another inscription (at the gates of Hell) in Canto III, if not all the way back to the opening lines of the Inferno, and simultaneously it points the way forward to the final revelation in the Godhead where the mysteries of the Trinity and the Incarnation are inscribed on Dante's heart. In Paradiso XXXIII this moment, significantly, is ushered in by the Virgin. If it is the "Maker's maker" who, communicating with her eyes alone, urges Dante to look upon the Godhead in Paradiso (XXXIII, 40-45), it is the "alto fattore" or High Maker himself who leaves the darkly colored words inscribed on the gates of Hell ["parole de colore oscuro . . . scritte al sommo d'una porta"] (III, 10-11). According to that inscription, Giustizia moved this Supreme Architect to create such a place, and the Architect used power, wisdom, and love - the first love, "l primo amore" (III, 6) - to construct it. This is the love that Dante-poet tells us moves the universe at the end of Paradiso, even though the words of the inscription in Inferno are still hard-“Maestro, il senso lor m'è duro" (III, 12)-for Dante-pilgrim to accept, or even understand. Among many other things, the Comedy traces Dante-pilgrim's education, ${ }^{33}$ his pilgrim's progress, with increasingly better comprehension of that "primo amore," the "amor che move il sole e l'altre stelle" of the poem's final line, a love whose flame was "relit" in the warmth of a mother's womb: "Nel ventre tuo si raccese l'amore, / per lo cui caldo ne l'etterna pace / così è germinato questo fiore" [Your womb relit the flame of love- / its heat has made this blossom seed / and flower in eternal peace] (Paradiso XXXIII, 7-9). ${ }^{34}$

\footnotetext{
${ }^{33}$ See Tonia Bernardi Triggiano, "Dante's Heavenly Lessons: Educative Economy in the Paradiso," Essays in Medieval Studies 26 (2010), 15-26.

${ }^{34}$ Hollander's translation. These words are part of Bernard of Clairvaux's prayer to the Virgin. Bernard of Clairvaux's presence in the Commedia, and at such a crucial moment, before Dante's final contemplation of the Godhead, would seem to reinforce the importance of the Incarnation and the pivotal role of Mary for Dante. See, in addition to the commentary of Freccero and Hollander on this passage, Steven Botterill's thorough Dante
} 
Over the course of his journey, Dante-pilgrim becomes a better reader/interpreter of the universe that Dante-poet has created. Do we as readers become better interpreters of this poetic universe? The poet has certainly left signposts along the way for his readers; I would suggest the tomb inscription is one of them. Virgil, the master/guide from whom Dante-pilgrim claims to have learned so much, however, reveals the limitations of his own interpretive horizons after their escape from the Minotaur. Commenting upon the landslide ("questa ruina" XII, 32) left by the earthquake at Christ's death, he notes that in that moment the universe felt love ("che l' universo sentisse amor" [XII, 41-42]), but then goes on to gloss this love as mere "concord," the prelude to chaos in the cyclical universe of pagan philosophy ("amor, per lo qual è chi creda / più volte il mondo in caòsso converso" [XII, 42-43]). ${ }^{35}$ Hollander has written about the moral situation of the reader in the Inferno: "We should try to honor the distinction the text itself clearly draws" between narrator and protagonist. ${ }^{36}$ That narrator, Dante-poet, shows us that Virgil is a sure guide for his protagonist, Dante-pilgrim. Virgil understands the overall design of Hell in the cold, analytical way of an Aristotle ("Do you not remember Aristotle's Ethics?" he asks Dante-pilgrim while sheltered behind Anastasius's tomb in XI, 79-80), but his "reading" and commentary on the earthquake are incomplete. He does not understand the figural significance of that literal quake; he perceives only the historical event and applies the faint light of classical reason, which Dante shows us in Limbo among the virtuous pagans (IV, 68-69; 103), because he is not prepared to interpret the allegorical, moral, and anagogical meanings revealed through the mystery of the Incarnation and the immensity of divine love.

Modern readers, according to our epigraph from Singleton, are not unlike Virgil in their inability to appreciate this figural density. It is, perhaps, the Renaissance (as Singleton suggests) that we have to blame for this - a period that found in the figural realism of Dante's vernacular a new way of reading, in which the "image of man eclipses the image of God," according to Auerbach's reading. ${ }^{37}$ Auerbach did more than anyone in the first part of the twentieth century to help us uncover the

and the Mystical Tradition: Bernard of Clairvaux in the Commedia (Cambridge: Cambridge University Press, 1994).

${ }^{35}$ Hollander's translation; on the philosophical background, see Hollander's note on these lines (Inferno, 230).

36 "Moral Situation of the Reader of Inferno," Lecture (February 1998), available online at the PDP.

${ }^{37}$ Auerbach, 202. 
figural density of Dante's work, as Dante's first readers may have perceived it, but Auerbach lays the blame for the Renaissance reinterpretation firmly at the feet of the poet himself:

Dante's work made man's Christian-figural being a reality, and destroyed it in the process of realizing it. The tremendous pattern was broken by the overwhelming power of the images it had to contain. The coarse disorderliness which resulted during the later Middle Ages from the farcical realism of the mystery plays is fraught with less danger to the figural-Christian view of things than the elevated style of such a poet, in whose work men learn to see and know themselves. ${ }^{38}$

In other words, Dante was a victim of his own success. And yet, a perusal of the early commentators on our tomb inscription demonstrates that precisely because "men learn to see and know themselves" in Dante's work, they thought they could learn to see and know God. Lifting the lid off a tomb, these commentators found a denial of that miraculous womb, through which the divine order made itself known in the mundane, making it possible for humans to recognize God in the human person of Christ; this is likewise reflected in the Godhead, where Dante-pilgrim sees our image, "nostra effige" (Paradiso XXXIII, 131), in the second person of the Trinity, the second of the three rings. ${ }^{39}$ The point is not to fixate on the human, but to see humanity as a figure for divinity. The fourteenth-century mystic Walter Hilton writes in his Ladder of Perfection (a work, not unlike Dante's, meant to guide the soul toward a more perfect contemplation of the Godhead) that "the love felt by a soul when grace enables it to contemplate God in man is more exalted, more spiritual, and more valuable than the fervor of devotion aroused by the contemplation of Jesus's manhood alone, however strong the outward signs of this love." ${ }^{, 40}$ Anastasius and Photinus went astray in their "abominable heresy," according to Dante and his early readers, because they focused on the humanity of Jesus's conception and birth.

Ronald L. Martinez's recent article on this tomb inscription has a splendid analysis of medieval "Anastasis images" and the Descent into Hell motif. ${ }^{41} \mathrm{He}$ focuses his interpretation on the Resurrection, as a

\footnotetext{
${ }^{38}$ Auerbach, 202.

${ }^{39}$ Oliver Davies notes that "Dante seems to be telling us that he sees the Incarnate son in the Trinity" ("Dante's Commedia and the Body of Christ" in ed. Montemaggi and Traherne, op. cit., p. 174).

${ }^{40}$ In ed. Bernard McGinn, 187.

${ }^{41}$ Martinez, 16-18.
} 
central tenet of Christian belief, on the "aborted resurrections" of the circle of heresy (Farinata, Cavalcante), and the irony of "a pope whose signifying name points not to his future resurrection with Christ, but to its opposite." ${ }^{42}$ Martinez goes on to suggest, however, that "this negative sense does not exhaust the meaning of the inscription as a sign, which also registers the full positive meaning of the name Anastasius by serving, near the entrance to lower Hell, as an act of witness of the triumphant descent and resurrection of Christ, the Anastasis." ${ }^{43}$ My analysis of the inscription on Anastasius's tomb in no way negates Martinez's interpretation; it complements it in many ways by expanding our vision out from the moment of harrowing and Resurrection to recall the Annunciation and the Incarnation. If, as Saverio Bellomo has suggested, "the early commentaries establish the horizon of expectations of the Commedia at its origins and allow us therefore to see it through the eyes of its first readers, ${ }^{\prime 44}$ then the bowel-movement death they insisted on attaching to Anastasius is not just another lurid detail. Though miserable, it is a fitting death (remember these early readers interpreted it as divine judgement, giudicio) for denying the Virgin birth. ${ }^{45}$ Dantepilgrim will comprehend this when he follows the loving gaze of the Virgin to the Godhead, where he will perceive "nostra effige" (our human likeness) within the Trinity. But here on the edge of the circle of heretics, literally staring into the abyss, Dante-pilgrim is not yet prepared for the light and warmth of that final vision. He is too close to the stench coming from the abyss, at the bottom of which, in the cold, dark place that is farthest from the Godhead in the physical and metaphysical universe as Dante has conceived it, he will see the anti-Trinity of Lucifer's three faces and crawl past his parti inferiori before he can begin again on that straight path - the via dritta he has lost for a time, and which Anastasius has lost forever in choosing to follow the "little light," Photinus, instead of the "true light" (Jn 1:9) of the Word made flesh.

\section{Baylor University}

${ }^{42}$ Martinez, 21-22.

${ }^{43}$ Martinez, 21.

44 "How to Read the Early Commentaries," in Interpreting Dante: Essays on the Traditions of Dante Commentary, ed. Paola Nasti and Claudia Rossignoli (Notre Dame, Indiana: University of Notre Dame Press, 2013), 84.

${ }^{45}$ As Robert Durling noted in his interpretation of the Inferno's design as analogous to the body, "the belly as locus of digestion is closely related to the belly as locus of generation" ("Deceit and Digestion," 74). 
Bibliography

Auerbach, Erich. Mimesis: The Representation of Reality in Western Literature. Translated by Willard R. Trask. Princeton, NJ: Princeton University Press, 1953.

Barolini, Teodolinda. The Undivine Comedy: Detheologizing Dante. Princeton, New Jersey: Princeton University Press, 1992. http://dx.doi.org/10.1515/9781400820764

Barsella, Susanna. In the Light of Angels: Angelology and Cosmology in Dante's Divina Commedia. Florence: Olschki, 2010.

Bellomo, Saverio. "How to Read the Early Commentaries." In Interpreting Dante: Essays on the Traditions of Dante Commentary, edited by Paola Nasti and Claudia Rossignoli, 84109. Notre Dame, Indiana: University of Notre Dame Press, 2013.

Bernardi Triggiano, Tonia. "Dante's Heavenly Lessons: Educative Economy in the Paradiso." Essays in Medieval Studies 26 (2010): $15-26$.

http://dx.doi.org/10.1353/ems.2010.0005

Blunt, John Henry. Dictionary of Sects, Heresies, Ecclesiastical Parties, and Schools of Thought. London, Oxford, and Cambridge, 1874.

Botterill, Steven. "Reading, Writing, and Speech in the Fourteenth- and Fifteenth- Century Commentaries on Dante's Comedy." In Interpreting Dante: Essays on the Traditions of Dante Commentary, edited by Paola Nasti and Claudia Rossignoli, 17-29. Notre Dame, Indiana: University of Notre Dame Press, 2013.

- Dante and the Mystical Tradition: Bernard of Clairvaux in the Commedia. Cambridge: Cambridge University Press, 1994. http://dx.doi.org/10.1017/CBO9780511611735

Davies, Oliver. "Dante's Commedia and the Body of Christ." In Dante's Commedia: Theology as Poetry, edited by Vittorio Montemaggi and Matthew Traherne, 161-79. Notre Dame, Indiana: University of Notre Dame Press, 2010.

Dartmouth Dante Project (DDP). Edited by Robert Hollander. 19882015. Accessed December 15, 2015. http://dante.dartmouth.edu.

Donne, John. The Complete English Poems. Edited by A. J. Smith. London: Penguin, 1996.

Durling, Robert M. "The Body Analogy." In The Divine Comedy: Inferno, edited and translated by Robert M. Durling and Ronald L. 
Martinez, 552-55 and 576-77. New York and Oxford: Oxford University Press, 1996.

- "Deceit and Digestion in the Belly of Hell." In Allegory and Representation, edited by Stephen J. Greenblatt, 61-93. London and Baltimore: Johns Hopkins University Press, 1981.

Durling, Robert M., and Richard L. Martinez, ed. and trans. The Divine Comedy: Inferno. New York and Oxford: Oxford University Press, 1996.

Forni, Pier Massimo. "Lectura Dantis: Inferno XI." Lectura Dantis 4 (1989). online at http://www.brown.edu/Departments/Italian Studies/LD/numbers/04.html

Fortescue, Adrian. "Henoticon." The Catholic Encyclopedia. New York: Robert Appleton, 1910. Vol. 7.

Freccero, John. "Introduction to Inferno." In The Cambridge Companion to Dante, edited by Rachel Jacoff, 172-91. Cambridge: Cambridge University Press, 1993. http://dx.doi.org/10.1017/CCOL0521417481.011

Hollander, Robert. "Dante and his Commentators." In The Cambridge Companion to Dante, edited by Rachel Jacoff, 226-36. Cambridge: Cambridge University Press, 1993.

—. Allegory in Dante's Commedia. Princeton: Princeton University Press, 1969.

Hollander, Robert, and Jean Hollander, ed. and trans. The Inferno. By Dante Alighieri. New York: Anchor Books, 2002.

Martinez, Robert L. "Anastasio papa guardo: The Descent into Hell and Dante's Heretics." Mediaevalia 29, no. 2 (2008): 15-30.

McGinn, Bernard, ed. The Essential Writings of Christian Mysticism. New York: Modern Library, 2006.

Moevs, Christian. "'Il punto che mi vinse': Incarnation, Revelation, and Self-Knowledge in Dante's Commedia." In Dante's Commedia: Theology as Poetry, edited by Vittorio Montemaggi and Matthew Traherne, 267-85. Notre Dame, Indiana: University of Notre Dame Press, 2010.

- The Metaphysics of Dante's Comedy. Oxford and New York: Oxford University Press, 2005.

http://dx.doi.org/10.1093/0195174615.001.0001

Nasti, Paola and Claudia Rossignioli. "Introduction." In Interpreting Dante: Essays on the Traditions of Dante Commentary, edited by 
Paola Nasti and Claudia Rossignioli, 1-16. Notre Dame, Indiana: University of Notre Dame Press, 2013.

Parker, Deborah. Commentary and Ideology: Dante in the Renaissance. Durham, North Carolina and London: Duke University Press, 1993.

Payton, Rodney J. A Modern Reader's Guide to Dante's Inferno. American University Studies, Series II, Romance Languages and Literatures: Vol. 191. New York and San Francisco: Peter Lang, 1992.

Princeton Dante Project (PDP). Edited by Robert Hollander. 1997-1999. Accessed December 15, 2015. http://etcweb.princeton.edu/dante/ index.html

Raffa, Guy P. The Complete Danteworlds: A Reader's Guide to the Divine Comedy. Chicago: University of Chicago Press, 2009. http://dx.doi.org/10.7208/chicago/9780226702872.001.0001

Ryan, Christopher. "The Theology of Dante." In The Cambridge Companion to Dante, edited by Rachel Jacoff, 136-52. Cambridge: Cambridge University Press, 1993. http://dx.doi.org/10.1017/ccol0521417481.009

Singleton, Charles S. Journey to Beatrice. Cambridge, MA: Harvard University Press, 1967. 